\title{
Effect of Seagrass Mixed With Casing Soil for the Cultivation of Mushrooms and Study of Bioaccumulation of Heavy Metals
}

\author{
Sevil Sener \\ Ege University, Aliaga Vocational School, Chemical Technology Department, \\ 35800 Izmir, Turkey
}

\section{INTRODUCTION}

It is increasingly important in fungi culture to utilize materials that help to reduce production costs. The production and use of a considerable number of cultivated products (cocoa shells, coconut shells, coffee pulp, corn stalks, and waste paper) have been used $(1,2)$ in Turkey which contributes to the economy and when carefully monitored, can also prevent environmental pollution when using natural resources. In countries where fungi culture is widely practiced, numerous composting formulae have been developed and put into practice based on the waste assets of the respective region (3, 4). Since Turkey is surrounded on three sides by the sea, it is possible that the abundance of seagrass available can be added to casing soil for cultivating mushrooms, which would also be a natural and green resource.

It is known that the heavy metal content of mushrooms has positive and negative effects on human health and the environment. Mushrooms have been used to remove radioactive metals from soil. Mercury, for instance, is one of the most poisonous elements of our ecosystem. The biological effects of $\mathrm{Hg}$ concentration through bioaccumulation in foods ingested by humans is also known. Due to its high accumulation ability, there is an increased interest to use wild

\footnotetext{
Corresponding autbor.

E-mail: sevil.sesener@gmail.com

E-mail: sevil.sener@ege.edu.tr

Tel: +90 2326160671

Fax: +90 2326161225
}

\begin{abstract}
Mushroom cultivation is becoming increasingly important around the world since it is a good food source. With declining availability of peat used for casing soil in the cultivation of mushrooms, the search for an alternative natural resource to add to the soil has become important. In this study, the value of seagrass added to casing soil for mushroom cultivation was investigated. For this purpose, the relation between bioaccumulation and the acid value of the casing soil containing different ratios of seagrass were studied, and the heavy metals in the cultivated mushrooms determined. Mushrooms bioaccumulate metals and will take them up from the casing soil. The metal content in seagrass is generally higher than peat; therefore, the transfer into the mushroom was also investigated in this study.
\end{abstract}

mushrooms as biomonitors for trace elements and radionuclides. For instance, they were used as direct monitors of ${ }^{134} \mathrm{Cs}$ and ${ }^{137} \mathrm{Cs}$ after the Chernobyl accident. Selenium is an essential trace element for humans and animals and is found in mushrooms (5-7). For this reason, researchers are interested not only in the economic aspect of fungi culture, but also in the effects of the possible heavy metal content on the environment and human health (8-10). It was found that due to their effective mechanisms, mushrooms absorb and bioaccumulate heavy metals much more rapidly than other agricultural products $(11,12)$.
Certain mushroom species are considered harmful and serve the purpose of protecting plants from the toxic effects created by heavy metals. For instance, mycorrhizal mushrooms help to protect pine and birch trees. They act like an armor around the trees in regions that are rich in metals, form a cover around the roots of the trees without penetrating into their capillary root cells and let most of the mineral intake of the trees pass through the tissues of the mushrooms.

Thus, mushrooms act as a filter and bioaccumulate heavy metals in high concentrations in their tissues.

Several studies have been conducted to determine the heavy metals in mushrooms in different regions of Turkey (13-19). However, the heavy metals content of mushrooms cultivated in casing soil supplemented with seagrass (4) has not been investigated so far.

The purpose of this study was to determine the heavy metal concentrations in mushrooms cultivated in casing soil to which seagrass was added in four different ratios. The correlation between the concentration and bioaccumulation of heavy metals was studied and the acid value of the casing soil was analyzed.

\section{EXPERIMENTAL}

\section{Turf-to-Seagrass Ratio Used for Growing Mushrooms}

The mushrooms used in this study were cultivated at Ege University, Bergama Vocational School of Higher Education, Turkey. The percent ratio of turf-to-seagrass used for the casing soil is listed in Table I. 


\section{Instrumentation and Reagents}

The analyses for metal content were performed using a Model Optima $^{\text {TM }} 2000$ DV inductively coupled plasma atomic emission spectrometer (ICP-OES) (PerkinElmer, Inc., Shelton, CT, USA). The optimized instrumental parameters are listed in Table II. The $\mathrm{pH}$ measurements were performed using the Eutech $^{\text {TM }}$ pH 700 meter (Thermo Scientific, USA). A Milli-Q ${ }^{\circledR}$ (18.2 $\mathrm{M} \Omega . \mathrm{cm}$ ) Integral Water Purification System was used to produce distilled de-ionized ultrapurified water (Millipore Corporation, USA).

Solvents of concentrated hydrochloric acid (37\%), nitric acid (65\%), and perchloric acid (70-72\%) (Merck, Germany) were used throughout this study. The $\mathrm{pH}$ adjustment of the solutions was performed with $0.1 \mathrm{M} \mathrm{NaOH}$ and $0.1 \mathrm{M} \mathrm{HCl}$ solutions (Merck, Germany). Main stock standard of 10 ppm was prepared. Then $0.5 \mathrm{ppm}$ of intermediate stock solution was prepared by dilution. Using this intermediate stock solution, solutions of $25 \mathrm{ppb}, 50 \mathrm{ppb}, 100 \mathrm{ppb}$, $200 \mathrm{ppb}, 300 \mathrm{ppb}$, and $400 \mathrm{ppb}$ were again prepared by dilution. For preparation of the solutions, Milli-Q distilled deionized water of
18.2 M $\Omega . \mathrm{cm}$ resistance (Millipore Corporation, USA) was used.

\section{Mushroom Samples}

The mushroom samples were brought to the laboratory in glass jars, cut into small pieces with a knife, and left to dry at room temperature. The dried samples were weighed (10 g) on a precision scale, brought to constant weight at $105^{\circ} \mathrm{C}$ in a drying oven, and then their moisture percentage calculated. Thus, the amount of dry matter in the mushrooms was obtained. The moisture and dry matter percentages of the mushrooms cultivated in the casing soil are listed in Table III. Every sample was homogenized and contained stalks and heads.

The mushroom samples were dissolved by wet decomposition (15), and the heavy metals measured as described below.

A $10 \mathrm{~g}$ amount of mushroom sample was placed into ISO-LAB 150-mL sterilized beakers, cultivated in the different casing soils ( $\mathrm{a}, \mathrm{b}, \mathrm{c}, \mathrm{d})$, dried at $105^{\circ} \mathrm{C}$, then $5 \mathrm{~mL}$ of concentrated $\mathrm{HCl}(37 \%)$, $5 \mathrm{~mL}$ of concentrated $\mathrm{HNO}_{3}(65 \%)$, $10 \mathrm{~mL}$ of concentrated $\mathrm{HClO}_{4}(70$ $72 \%$ ), and a few pieces of glass (as

TABLE I

Percent Ratio of Turf-to-Seagrass Used in this Study

\begin{tabular}{lccc}
\hline Casing Soil & $\begin{array}{c}\text { *Casing Soil } \\
\text { Symbol }\end{array}$ & $\begin{array}{c}\text { **Casing Soil }_{\text {Heavy Metals }} \\
\text { Concentration }\end{array}$ & $\begin{array}{c}\text { *** Mushroom } \\
\text { Heavy Metals } \\
\text { Concentration }\end{array}$ \\
\hline $100 \%$ Turf & $\mathrm{a}$ & $\mathrm{X}_{\mathrm{a}}$ & $\mathrm{C}_{\mathrm{a}}$ \\
$90 \%$ Turf + 10\% Seagrass & $\mathrm{b}$ & $\mathrm{X}_{\mathrm{b}}$ & $\mathrm{C}_{\mathrm{b}}$ \\
$80 \%$ Turf + 20\% Seagrass & $\mathrm{c}$ & $\mathrm{X}_{\mathrm{c}}$ & $\mathrm{C}_{\mathrm{c}}$ \\
$100 \%$ Seagrass & $\mathrm{d}$ & $\mathrm{X}_{\mathrm{d}}$ & $\mathrm{C}_{\mathrm{d}}$ \\
\hline
\end{tabular}

*(a,b,c,d): The symbols of different types casing soil used.(a: $100 \%$ turf used; b: $90 \%$ Turf $+10 \%$ Seagrass used: c: $80 \%$ Turf $+20 \%$ Seagrass used; $d: 100 \%$ Seagrass used). ** $(\mathrm{Xa}, \mathrm{Xb}, \mathrm{Xc}, \mathrm{Xd})$ : The symbols of heavy metals concentration $(\mathrm{X}: \mathrm{Cu}, \mathrm{Cd}, \mathrm{Ni}, \mathrm{Co}$, $\mathrm{Zn}, \mathrm{Sn}, \mathrm{Mn}, \mathrm{Fe}, \mathrm{Cr}, \mathrm{As}, \mathrm{Pb})$ of different types of casing soil (a,b,c,d). For example: Xa : Heavy metals concentration measured at $100 \%$ turf casing soil).

*** $(\mathrm{Ca}, \mathrm{Cb}, \mathrm{Cc}, \mathrm{Cd})$ : The symbols of heavy metals concentration $(\mathrm{C}: \mathrm{Cu}, \mathrm{Cd}, \mathrm{Ni}, \mathrm{Co}$, $\mathrm{Zn}, \mathrm{Sn}, \mathrm{Mn}, \mathrm{Fe}, \mathrm{Cr}, \mathrm{As}, \mathrm{Pb}$ ) of mushrooms grown in different types of casing soil (a,b,c,d). For example: Ca : Heavy metals concentration in mushrooms measured at $100 \%$ turf casing soil).

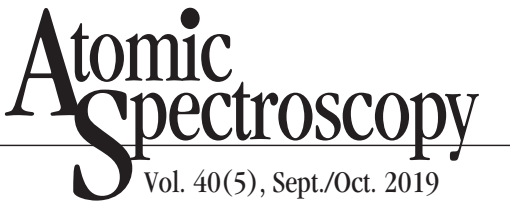

boiling stones) were added. A stirring rod was put into each beaker, which was covered with a watch

TABLE II

Optima 2000 DV ICP-OES Operating Conditions

\begin{tabular}{ll}
\hline Viewing Height & $12 \mathrm{~mm}$ \\
RF Power & $750-1500 \mathrm{~W}$ \\
Spray Chamber & Cyclonic \\
Nebulizer & Meinhard ${ }^{\circledR}$ \\
Nebulizer Flow & $0.8 \mathrm{~L} / \mathrm{min}$ \\
Plasma Gas Flow & $15 \mathrm{~L} / \mathrm{min}$ \\
Plasma View & Axial or Radial \\
Auxiliary Gas Flow & $0.2 \mathrm{~L} / \mathrm{min}$ \\
Read Delay & $90 \mathrm{sec}$ \\
Read Parameters & $2.0 \mathrm{~min}$, \\
& $5 \mathrm{max}$. \\
Peristaltic Pump & \\
$\quad$ Flow Rate & $0.2-5 \mathrm{~mL} / \mathrm{min}$ \\
Injector & Alumina, \\
& $2.0 \mathrm{~mm}$ i.d \\
Sample Aspiration & \\
rate & $2.0 \mathrm{~mL} / \mathrm{min}$ \\
Sample Pump & \\
Rate & $25 \mathrm{rpm}$ \\
Sample Tubing & Standard \\
& $0.76 \mathrm{~mm}$ i.d \\
Standard \\
Drain Tubing & $1.14 \mathrm{~mm}$ i.d \\
Quartz Torch & Single slot \\
Sample Capillary & Teflon ${ }^{\circledR}$ \\
& $1 \mathrm{~mm} \mathrm{i.d}$ \\
Replicates & 3 \\
\hline & \\
&
\end{tabular}

TABLE III

Moisture vs. Dry Matter

Percentage of Casing Soil

\begin{tabular}{ccc}
\hline $\begin{array}{c}\text { *Casing } \\
\text { Soil }\end{array}$ & $\begin{array}{c}\text { Moisture } \\
(\%)\end{array}$ & $\begin{array}{c}\text { Dry Matter } \\
(\%)\end{array}$ \\
\hline $\mathrm{a}^{*}$ & 72.5 & 27.5 \\
$\mathrm{~b}^{*}$ & 52 & 48 \\
$\mathrm{c}^{*}$ & 70.45 & 29.55 \\
$\mathrm{~d}^{*}$ & 68.40 & 31.60 \\
\hline
\end{tabular}

*a: Casing soil of $100 \%$ Turf.

*b: Casing soil of $90 \%$ Turf $+10 \%$ Seagrass.

${ }^{*} \mathrm{c}$ : Casing soil of $80 \%$ Turf $+20 \%$ Seagrass.

*d: Casing soil of $100 \%$ Seagrass. 
glass and left standing overnight. Then $10 \mathrm{~mL}$ of distilled water was added to the beakers, slowly heated to $200{ }^{\circ} \mathrm{C}$, and occasionally stirred for 15 minutes with the stirring rod. Heating and stirring continued until the entire organic content of the mushrooms degraded, oxidized, and evaporated (takes about one day). Then $25 \mathrm{~mL}$ of distilled water was added to the beakers and heated until dryness. After this stage, another $50 \mathrm{~mL}$ of distilled water was added to the beaker, heated to $50{ }^{\circ} \mathrm{C}$ for about 5 to 7 minutes, and the solution filtered into 250-mL volumetric flasks through ISOLAB blue strip filter paper. The content of the beakers was rinsed through the filter paper with $15 \mathrm{~mL}$ distilled water at least four times. The filter papers were also washed four times with distilled water. Then the volumetric flasks were filled to volume with ultrapure water. The same operation was repeated for four different casing soils prepared as follows: (a) $100 \%$ Turf, (b) $90 \%$ Turf $+10 \%$ Seagrass added, (c) 80\% Turf $+20 \%$ Seagrass, (d) 100\% Seagrass).

\section{Analysis of Heavy Metals Concentration}

The different casing soils and the concentrations of the heavy metal ions of the mushrooms cultivated in these soils were included in the solution by wet decomposition (Xa, $\mathrm{Xb}, \mathrm{Xc}, \mathrm{Xd})(\mathrm{Ca}, \mathrm{Cb}, \mathrm{Cc}, \mathrm{Cd})$, measured and calculated by ICP-OES.

\section{RESULTS AND DISCUSSION}

The metals concentration in the mushroom species is closely related to the acidity of the acid value of the soil and the ecosystem in which the mushrooms are cultivated. According to the data presented in the literature, heavy metals concentration in mushrooms is closely related to the heavy metals concentration in the casing soil $(17,20,21)$.
Studies show that the analysis of heavy metals is important in fungi culture $(17,20,22)$. It was observed that the concentration of heavy metals depended on the acid value of the casing soil in which the mushrooms were cultivated. The presence of compounds that can bond with the metals in the structure of a mushroom may cause bioaccumulation which increases in acid-rich soils (with a low acid value) $(22,23)$.

The heavy metals concentrations, calculated for the casing soils and the mushrooms cultivated in such casing soils, are listed in Tables IV and V. As can be, the seagrass contains high concentrations of $\mathrm{Cu}, \mathrm{Cd}, \mathrm{Ni}, \mathrm{Co}, \mathrm{Zn}$, and $\mathrm{Sn}$. Interestingly, the mushrooms cultivated in seagrass display similar metal content distribution. On the other hand, $\mathrm{Fe}, \mathrm{Cr}$, As, and $\mathrm{Pb}$ concentrations are low in seagrass similar to the content in mushrooms cultivated in pure seagrass. It is noteworthy that the most harmful heavy metals $\mathrm{As}$ and $\mathrm{Pb}$ are very low in seagrass compared to the amount measured for turf, indicating that seagrass is a good candidate as an alternative for turf to cultivating mushrooms.

The acid values in mushrooms, cultivated in these casing soils consisting of a mixture of seagrass in four different percentages (4), are listed in Table VI.

The concentrations of the heavy metals $\mathrm{Cu}, \mathrm{Cd}, \mathrm{Ni}, \mathrm{Co}, \mathrm{Zn}, \mathrm{Pb}$, and As as well as $\mathrm{Sn}, \mathrm{Mn}, \mathrm{Fe}$, and $\mathrm{Cr}$ in these casing soils and the mushrooms cultivated in such soils are represented in Figures 1 and 2.

Figure 1 shows that the concentration of $\mathrm{Co}, \mathrm{Cd}, \mathrm{Ni}, \mathrm{Zn}, \mathrm{Pb}$, and As increases as the percentage of the seagrass in the casing soil decreases. Figure 2 shows that the concentration of $\mathrm{Sn}, \mathrm{Mn}, \mathrm{Fe}$, and $\mathrm{Cr}$ in mushrooms grown in these soils increases as the percentage of the seagrass in the casing soil decreases.

Table VII lists the maximum amounts of elements allowable in the human body to maintain good health $(24,25)$, the amount of elements found in the different casing soils (Xa, Xb , Xc , Xd), and in the mushrooms cultivated in the different casing soils $(\mathrm{Ca}, \mathrm{Cb}, \mathrm{Cc}, \mathrm{Cd})$.

TABLE IV

Calculated Heavy Metals Concentration $(\mathrm{mg} / \mathrm{kg})$ in the Casing Soils

\begin{tabular}{lrrrr}
\hline & ${ }^{*} \mathrm{Xa}$ & ${ }^{*} \mathrm{Xb}$ & ${ }^{*} \mathrm{Xc}$ & ${ }^{*} \mathrm{Xd}$ \\
\hline $\mathrm{Cu}$ & 0.38 & 1.33 & 4.31 & $20.45 \pm 0.02$ \\
$\mathrm{Cd}$ & 0.4 & 2.3 & 6.1 & $19.6 \pm 0.02$ \\
$\mathrm{Ni}$ & 2.5 & 4.8 & $15.9 \pm 0.06$ & $32.5 \pm 0.033$ \\
$\mathrm{Co}$ & 0.7 & 2.11 & 5.2 & $20.5 \pm 0.02$ \\
$\mathrm{Zn}$ & 0.13 & 0.99 & 7.2 & $20.1 \pm 0.02$ \\
$\mathrm{Sn}$ & 0.4 & 3.12 & 7.04 & $18.9 \pm 0.019$ \\
$\mathrm{Mn}$ & $20.5 \pm 0.02$ & $10 \pm 0.01$ & 3.2 & 0.9 \\
$\mathrm{Fe}$ & $57.6 \pm 0.058$ & $23 \pm 0.023$ & $10.5 \pm 0.01$ & 2.3 \\
$\mathrm{Cr}$ & $20.36 \pm 0.02$ & $17.47 \pm 0.017$ & 6.67 & 0.32 \\
$\mathrm{As}$ & $36.36 \pm 0.036$ & $16.47 \pm 0.016$ & 7.67 & 0.32 \\
$\mathrm{~Pb}$ & $46.2 \pm 0.046$ & $19.88 \pm 0.02$ & $15.02 \pm 0.015$ & 0.34 \\
\hline $\mathrm{Xa}$ & & 19.015 &
\end{tabular}

*Xa : heavy metals concentration in $100 \%$ Turf.

$\mathrm{Xb}$ : heavy metals concentration in $90 \%$ Turf $+10 \%$ Seagrass.

Xc : heavy metals concentration in $80 \%$ Turf $+20 \%$ Seagrass.

$\mathrm{Xd}$ : heavy metals concentration in $100 \%$ Seagrass. 
TABLE V

Heavy Metals Concentration $(\mathrm{mg} / \mathrm{kg}$ ) in the Mushrooms Cultivated in Different Casing Soils (\%)

\begin{tabular}{lrrrr}
\hline & ${ }^{*} \mathrm{Ca}$ & ${ }^{*} \mathrm{Cb}$ & ${ }^{*} \mathrm{Cc}$ & ${ }^{*} \mathrm{Cd}$ \\
\hline $\mathrm{Cu}$ & 0.39 & 1.4 & 4.43 & $20.45 \pm 0.02$ \\
$\mathrm{Cd}$ & 0.4 & 2.42 & 6.44 & $19.6 \pm 0.02$ \\
$\mathrm{Ni}$ & 2 & 5.15 & $20.4 \pm 0.02$ & $39.5 \pm 0.04$ \\
$\mathrm{Co}$ & 0.5 & 2.06 & 5.68 & $23.7 \pm 0.024$ \\
$\mathrm{Zn}$ & 0.1 & 1.2 & 7.3 & $20.14 \pm 0.02$ \\
$\mathrm{Sn}$ & 0.6 & 3.44 & 7.42 & $18.4 \pm 0.018$ \\
$\mathrm{Mn}$ & $19.05 \pm 0.02$ & 9.58 & 4.54 & 0.5 \\
$\mathrm{Fe}$ & $47.6 \pm 0.05$ & $24.34 \pm 0.024$ & $11.08 \pm 0.011$ & 2.5 \\
$\mathrm{Cr}$ & $20.54 \pm 0.02$ & $10.51 \pm 0.01$ & 5.48 & 0.25 \\
$\mathrm{As}$ & $30.32+0.03$ & $18.35 \pm 0.018$ & 7.36 & 0.38 \\
$\mathrm{~Pb}$ & $44.2 \pm 0.044$ & $22.21 \pm 0.022$ & $13.23 \pm 0.013$ & 0.34 \\
\hline
\end{tabular}

${ }^{*} \mathrm{Ca}$ : heavy metals concentration in mushrooms grown in $100 \%$ Turf.

$\mathrm{Cb}$ : heavy metals concentration in mushrooms grown in $90 \%$ Turf $+10 \%$ Seagrass

Cc : heavy metals concentration in mushrooms grown in $80 \%$ Turf $+20 \%$ Seagrass.

$\mathrm{Cd}$ : heavy metals concentration in mushrooms grown in 100\% Seagrass).

TABLE VI

Acid Values of Casing Soil With or Without Seagrass

\begin{tabular}{ccccc}
\hline & $* \mathrm{a}$ & $* \mathrm{~b}$ & ${ }^{*} \mathrm{c}$ & $* \mathrm{~d}$ \\
\hline \multirow{2}{*}{ Acid values } & 6.79 & 6.9 & 7.3 & 8.01 \\
\hline
\end{tabular}

*a: casing soil of $100 \%$ Turf.

b: casing soil of $90 \%$ Turf $+10 \%$ Seagrass.

c: casing soil of $80 \%$ Turf $+20 \%$ Seagrass.

d: casing soil of $100 \%$ Seagrass.

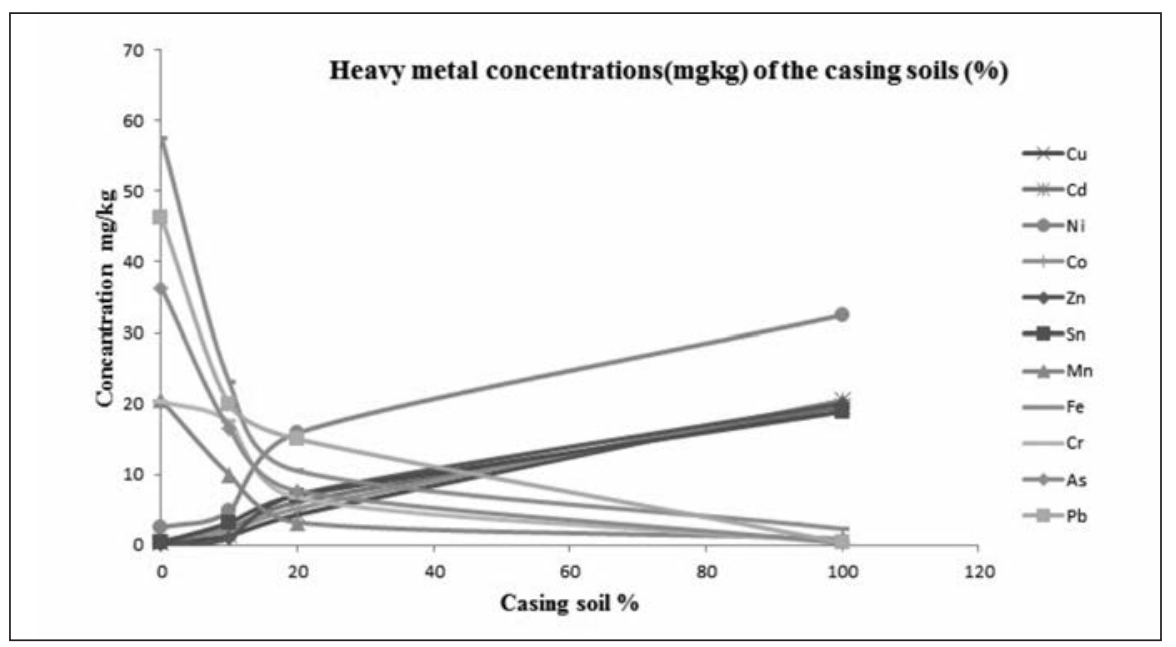

Fig. 1. Heavy metals concentration ( $\mathrm{mg} / \mathrm{kg}$ ) in the casing soil (\%).

As seen from Table VII, the cultivated mushrooms grown in only seagrass is not suitable for $\mathrm{Cu}$ concentrations. However, casing soil mixed with seagrass is suitable for the determination of $\mathrm{Zn}, \mathrm{Sn}, \mathrm{Mn}$, $\mathrm{Fe}, \mathrm{Cr}$, and $\mathrm{Pb}$ concentrations. Cultivated mushrooms grown only in seagrass is also suitable for assessing arsenic concentrations.

\section{CONCLUSION}

In this study, seagrass was mixed with casing soil for growing mushrooms. It was found that it not only increases the volume of the soil, but also increases the soil's acid value (decreases the acidity) and the uptake of heavy metals such as $\mathrm{Cu}, \mathrm{Cd}, \mathrm{Ni}, \mathrm{Co}, \mathrm{Zn}, \mathrm{Pb}$, and As since these metals bioaccumulate in the mushrooms. It was also observed that as the acid value, hence the percentage (\%) of seagrass in the casing soil, increases, the concentration of $\mathrm{Sn}, \mathrm{Mn}, \mathrm{Fe}$, and $\mathrm{Cr}$ decreases. Thus, these metals do not bioaccumulate in the cultivated mushroom when a higher percentage (\%) of seagrass is mixed with the casing soil. Since the amount of turf in nature has been decreasing, seagrass offers a good, green, and economical alternative to increasing the amount of soil necessary for mushroom cultivation.

\section{ACKNOWLEDGMENT}

The author thanks EBILTEM for providing the financial support under Project No. 2008/BMYO/ 003. Also gratefully acknowledged are Prof. Dr. Mithat Yuksel, Dr. Erkan Eren, and Dr. Mehmet Çetin for their support during this study.

Received February 13, 2019.

\section{REFERENCES}

1. R.C. Bermudez, N. Garcia, P. Gross and $M$. Serrano, Micologia Aplicada International 13(1), 25 (2001).

2. E. Baysal and H. Peker, Teknoloji 3(4), 9 (2001).

3. C. Gülser and A. Peksen, Bioresource Technol. 88(2), 153 (2003). DOI: https://doi.org/10.1016/S09608524(02)00279-1 


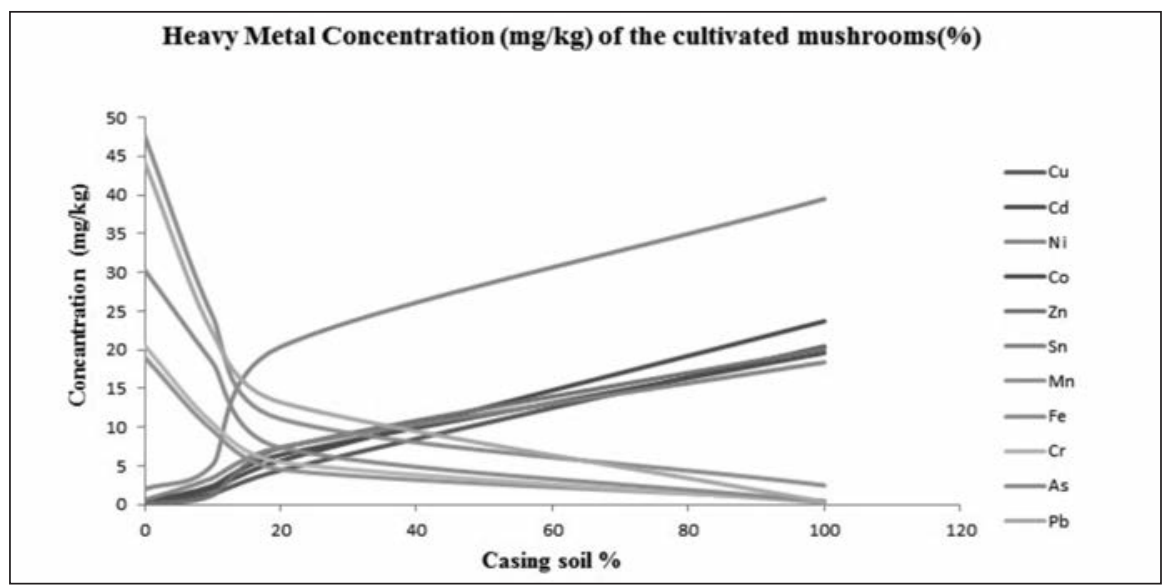

Fig. 2. Heavy metals concentration ( $\mathrm{mg} / \mathrm{kg}$ ) of the cultivated mushrooms (\%).

TABLE VII

Maximum Allowable Heavy Metals Concentration ( $\mathrm{mg} / \mathrm{kg}$ ) for Humans From Cultivated Mushrooms, Casing Soil Consisting of Turf and/or Seagrass

\begin{tabular}{lrrrrrrrrr}
\hline & ${ }^{*} \mathrm{H}$ & ${ }^{*} \mathrm{Ca}$ & ${ }^{*} \mathrm{Cb}$ & ${ }^{*} \mathrm{Cc}$ & ${ }^{*} \mathrm{Cd}$ & ${ }^{*} \mathrm{Xa}$ & ${ }^{*} \mathrm{Xb}$ & ${ }^{*} \mathrm{Xc}$ & ${ }^{*} \mathrm{Xd}$ \\
\hline $\mathrm{Cu}$ & 8 & 0.39 & 1.4 & 4.43 & 20.45 & 0.38 & 1.33 & 4.31 & 20.45 \\
$\mathrm{Cd}$ & 60 & 0.4 & 2.42 & 6.44 & 19.6 & 0.4 & 2.3 & 6.1 & 19.6 \\
$\mathrm{Ni}$ & 2 & 2 & 5.15 & 20.4 & 39.5 & 2.5 & 4.8 & 15.9 & 32.5 \\
$\mathrm{Co}$ & 1.1 & 0.5 & 2.06 & 5.68 & 23.7 & 0.7 & 2.11 & 5.2 & 20.5 \\
$\mathrm{Zn}$ & 120 & 0.1 & 1.2 & 7.3 & 20.14 & 0.13 & 0.99 & 7.2 & 20.1 \\
$\mathrm{Sn}$ & 30 & 0.6 & 3.44 & 7.42 & 18.4 & 0.4 & 3.12 & 7.04 & 18.9 \\
$\mathrm{Mn}$ & 20 & 19.05 & 9.58 & 4.54 & 0.5 & 20.5 & 10 & 3.2 & 0.9 \\
$\mathrm{Fe}$ & 250 & 47.6 & 24.34 & 11.08 & 2.5 & 57.6 & 23 & 10.5 & 2.3 \\
$\mathrm{Cr}$ & 100 & 20.54 & 10.51 & 5.48 & 0.25 & 20.36 & 17.47 & 6.67 & 0.32 \\
$\mathrm{As}$ & 3 & 30.32 & 18.35 & 7.36 & 0.38 & 36.36 & 16.47 & 7.67 & 0.32 \\
$\mathrm{~Pb}$ & 200 & 44.2 & 22.21 & 13.23 & 0.34 & 46.2 & 19.88 & 15.02 & 0.34 \\
\hline
\end{tabular}

${ }^{*} \mathrm{H}$ : maximum allowable heavy metals concentrations in the human body.

*Ca : heavy metals concentration in mushrooms grown in $100 \%$ Turf.

$\mathrm{Cb}$ : heavy metals concentration in mushrooms grown in $90 \%$ Turf $+10 \%$ Seagrass.

Cc : heavy metals concentration in mushrooms grown in $80 \%$ Turf $+20 \%$ Seagrass.

Cd : heavy metals concentration in mushrooms grown in 100\% Seagrass.)

*Xa : heavy metals concentration in $100 \%$ Turf.

$\mathrm{Xb}$ : heavy metals concentration in $90 \%$ Turf $+10 \%$ Seagrass.

Xc : heavy metals concentration in $80 \%$ Turf $+20 \%$ Seagrass.

Xd : heavy metals concentration in $100 \%$ Seagrass).

4. E. Eren and K. Boztok, Igdır Üni. Fen Bilimleri Enstitüsü Dergisi 3(1), 9 (2013).

5. J. Vetter and E. Berta, Food Control 16,113 (2005).

6. V. Gergely, K.M. Kubachka, S. Mounicou, P. Fodor and J.A. Caruso, J. of Chromotography A 1101, 94 (2006).

7. J.T.V. Elteren, U.D. Woroniecka and K.J. Kroon, Chemosphere
11. P.C. Onianwa, A.O. Adeyemo, O.E. Idowu and E.E. Ogabiela, Food Chem. 72, 89 (2001). DOI: https://doi.org/10.1016/S03088146(00)00214-4

12. M. Soylak, A.U. Karatepe, L. Elçi and M. Dogan, Turkish J. of Chem. 27, 235 (2003).

13. A. Demirbaş, Food Chemistry 68, 415 (2000). DOI: https://doi.org/10.1016/S03088146(99)00210-1

14. M. Is1loglu, F. Y1lmaz and M. Merdivan, Food Chem. 73, 169 (2001).

15. M. Tüzen, M. Özdemir and A. Demirbaş, Food Chem. 63(2), 247 (1998). DOI: https://doi.org/10.1016/S03088146(97)00225-2

16. I. Türkekul, M. Elmastas and M. Tüzen, Food Chem. 84, 389 (2003). DOI: https://doi.org/10.1016/S03088146(03)00245-0

17. E. Sesli and M. Tüzen, Food Chem. 65(4), 453 (1999). DOI: https://doi.org/10.1016/S03088146(98)00194-0

18. A. Y1ld1z, M. Karakaplan and F. Aydin, Food Chem. 61(1-2), 127 (1998). DOI: https://doi.org/10.1016/S03088146(97)00066-6

19. H. Sivrikaya, L. Bacak, A. Saraçbası, I. Toroglu and H. Eroglu, Food Chem. $79(2), 173$ (2002). DOI: https://doi.org/10.1016/S03088146(02)00128-0

20. C.H. Gast, E. Jensen, J. Bierling and L. Haonstran, Chemosphere 75 , 417 (1988).

21. A. Demirbas, Food Chem. 78, 89 (2002). DOI: https://doi.org/10.1016/S03088146(01)00389-2

22. A. Demirbas, Food Chem. 74, 293 (2001).

23. A. Demirbas, Food Chem. 75, 453 (2001). DOI: https://doi.org/10.1016/S0308 8146(01)00236-9

24. T. Seven, B. Can, B.N. Darende, S. Ocak, Ulusal Çevre Bilimleri Arastırma Dergisi, 1(2), 91(2018).

25. I. Pektes, Vücudumuzdaki Metalurji, 2th ed., Ajans 007, Ankara, Turkey (2017). 